\title{
Cytotoxic effects of essential oils from three Lippia gracilis Schauer genotypes on HeLa, B16, and MCF-7 cells and normal human fibroblasts
}

\author{
J.O. Melo ${ }^{1}$, A.L. Fachin ${ }^{2}$, W.F. Rizo ${ }^{2}$, H.C.R. Jesus ${ }^{3}$, M.F. Arrigoni-Blank ${ }^{1}$, \\ P.B. Alves ${ }^{3}$, M.A. Marins ${ }^{2}$, S.C. França' ${ }^{2}$ and A.F. Blank ${ }^{1}$ \\ 'Programa de Pós-Graduação em Biotecnologia de Recursos Naturais, \\ Universidade Federal de Sergipe, São Cristóvão, SE, Brasil \\ ${ }^{2}$ Programa de Pós-Graduação em Biotecnologia, \\ Universidade de Ribeirão Preto, Ribeirão Preto, SP, Brasil \\ ${ }^{3}$ Departamento de Química, Universidade Federal de Sergipe, São Cristóvão, \\ SE, Brasil \\ Corresponding author: A.F. Blank \\ E-mail: afblank@ufs.br
}

Genet. Mol. Res. 13 (2): 2691-2697 (2014)

Received March 14, 2013

Accepted November 1, 2013

Published April 8, 2014

DOI http://dx.doi.org/10.4238/2014.April.8.12

\begin{abstract}
This study aimed to evaluate the chemical composition of the essential oils from three genotypes of Lippia gracilis Schauer (Verbenaceae) and investigate the cytotoxic activities of these oils. Essential oils were extracted from the leaves using a Clevengertype apparatus, and chemical analysis was performed using a gas chromatograph coupled to a mass spectrometer and flame ionization detector. 3T3, MRC5, B16, HeLa, and MCF-7 cell lines were used to study the in vitro cytotoxicity of the essential oils, and the level of cell death was determined using the 3-(4,5-dimethylthiazol-2-yl)-2,5diphenyltetrazolium bromide test with three replicates. The cytotoxic activity was expressed as the concentration that inhibited $50 \%$ of cell
\end{abstract}


growth. The main compound in the essential oil of LGRA-106 was thymol (40.52\%), while LGRA-109 and LGRA-201 contained 45.84 and $32.60 \%$ carvacrol, respectively, as their major compound. The essential oils of $L$. gracilis showed cytotoxic activity against both normal and tumor cells at concentrations below $100 \mu \mathrm{g} / \mathrm{mL}$; this demonstrated the antitumor potential of these essential oils, which should be further investigated.

Key words: Lippia gracilis; Germplasm; Volatile oil; Thymol; Carvacrol; Antitumor potential

\section{INTRODUCTION}

Worldwide, cancer remains a public health issue of the 21 st century. The World Health Organization estimates that there will be 520,000 new cases of cancer in 2012 and 2013 in Brazil (Instituto Nacional do Câncer, 2012). Plants have been globally used for medicinal purposes (Hernández et al., 2003), and the correlation between chemical structure and pharmacological properties has been analyzed to determine their efficacy (Duarte et al., 2005). Among studied plants, over 1000 species exhibit significant antitumor activity (Mukherjee et al., 2001; Ferraz et al., 2005).

In this context, new plant-based drugs with anticancer effects have become an important alternative cancer treatment that is being studied. The genus Lippia (family: Verbenaceae) includes approximately 200 species of herbs, shrubs, and small trees. These plants are mainly distributed in all countries of South and Central America and the tropical areas of Africa. Besides their medicinal use, the leaves of most species are used as food seasoning (Pessoa et al., 2005). L. gracilis plants have been used as antimicrobial and antiseptic (Pessoa et al., 2005; Albuquerque et al., 2006), antinociceptive and anti-inflammatory agents (Guilhon et al., 2011), and they exhibited larvicidal activity (concentration that inhibited $50 \%$ of cell growth $\left(\mathrm{LC}_{50}\right) \cong$ 98 ppm) against Aedes aegypti (Silva et al., 2008). In addition, Lippia alba exhibited cytotoxic activity against HeLa cells (Mesa-Arango et al., 2009), while Lippia citriodora, Lippia dulcis, and Lippia origanoides exhibited cytotoxic activity against Vero cells (Correa-Royero et al., 2010). Moreover, in vivo tests indicated that the essential oil of Lippia microphylla exhibited moderate antitumor activity (Xavier, 2011). Despite the potential application of L. gracilis, no study on the cytotoxic effects of its essential oil has been conducted yet. Thus, this study aimed to evaluate the chemical composition and cytotoxic activity of the essential oils from three genotypes of L. gracilis.

\section{MATERIAL AND METHODS}

\section{Plant material}

The leaves of three genotypes of L. gracilis Schauer, LGRA-106, LGRA-109, and LGRA-201, were collected in the Active Germplasm Bank of the Federal University of Sergipe, which is located at the Research Farm "Campus Rural da UFS" in São Cristóvão, Sergipe State, Brazil, at the latitude $11^{\circ} 00^{\prime} \mathrm{S}$ and longitude $37^{\circ} 12^{\prime} \mathrm{W}$ (Table 1). 
Table 1. Genotypes of Lippia gracilis collected in the Active Germplasm Bank of the Federal University of Sergipe.

\begin{tabular}{|c|c|c|c|c|}
\hline Genotype code & Scientific name & Origin & Geographic data & Voucher No. \\
\hline LGRA-106 & Lippia gracilis & Tomar do Geru, SE, Brazil & $11^{\circ} 19^{\prime} 16.7^{\prime \prime} \mathrm{S} ; 37^{\circ} 55^{\prime} 09.2^{\prime \prime} \mathrm{W}$ & 9205 \\
\hline LGRA-109 & Lippia gracilis & Tomar do Geru, SE, Brazil & $11^{\circ} 19^{\prime} 0.7^{\prime \prime} \mathrm{S} ; 37^{\circ} 55^{\prime} 16.9^{\prime \prime} \mathrm{W}$ & 9207 \\
\hline LGRA-201 & Lippia gracilis & Tomar do Geru, SE, Brazil & $11^{\circ} 23^{\prime} 38.7^{\prime \prime} \mathrm{S} ; 38^{\circ} 00^{\prime} 54.1^{\prime \prime} \mathrm{W}$ & 9206 \\
\hline
\end{tabular}

\section{Essential oil extraction}

The plant material was dried at $40 \pm 1{ }^{\circ} \mathrm{C}$ in a circulating air-drying oven for five days. The essential oils were extracted by hydrodistillation with a Clevenger-type apparatus for 140 min (Ehlert et al., 2006). Essential oils were stored at $-20^{\circ} \pm 2^{\circ} \mathrm{C}$ in amber bottles until the chemical analysis and bioassays were performed. The essential oil content was calculated and expressed as a percentage (v:w). Carvacrol and thymol standards were obtained from SigmaAldrich (St. Louis, MO, USA).

\section{Chemical analysis}

The chemical composition of the essential oils was analyzed using a gas chromatograph coupled to a mass spectrometer (GC-MS) (Shimadzu, model QP 5050A) equipped with an AOC-20i auto injector (Shimadzu) and a fused-silica capillary column (5\% phenyl/95\% dimethylpolysiloxane, $30 \mathrm{~m} \times 0.25-\mathrm{mm}$ ID, $0.25-\mu \mathrm{m}$ film, J\&W Scientific). Helium was used as the carrier gas at a flow rate of $1.2 \mathrm{~mL} / \mathrm{min}$. The temperature program was as follows: $50^{\circ} \mathrm{C}$ for $1.5 \mathrm{~min}$, an increase of $4^{\circ} \mathrm{C} / \mathrm{min}$ to $200^{\circ} \mathrm{C}$, an increase of $15^{\circ} \mathrm{C} / \mathrm{min}$ to $250^{\circ} \mathrm{C}$, and $250^{\circ} \mathrm{C}$ for $5 \mathrm{~min}$. The injector temperature was $250^{\circ} \mathrm{C}$, and the detector (or interface) temperature was $280^{\circ} \mathrm{C}$. The injection volume of ethyl acetate was $0.5 \mu \mathrm{L}$, the partition rate of the injected volume was 1:87, and the column pressure was $64.20 \mathrm{kPa}$. The mass spectrometer conditions were as follows: ionic capture detector impact energy, $70 \mathrm{eV}$; scanning speed, $0.85 \mathrm{scans} / \mathrm{s}$; and range, 40 to $550 \mathrm{Da}$.

The chemical constituents were quantified by GC with flame ionization detection using a Shimadzu GC-17A system (Shimadzu Corporation, Kyoto, Japan) equipped with a ZB5MS (5\% phenyl-arylene/95\% dimethylpolysiloxane) fused silica capillary column (30 $\mathrm{m} \mathrm{x}$ $0.25-\mathrm{mm}$ ID $\times 0.25-\mu \mathrm{m}$ film thickness) from Phenomenex (Torrance, CA, USA) under the same conditions described for GC-MS. The amount of each constituent was determined by area normalization (\%). The concentrations were calculated from the GC peak areas and arranged in order of GC elution.

The essential oil components were identified by comparison of mass spectra with mass spectra available on database (NIST05 and WILEY8) libraries. Additionally, retention index values were compared with those in the literature (Adams, 2007), and the relative retention indices were determined according to Vandendool and Kratz (1963) using a homologous series of $n$-alkanes $\left(\mathrm{C}_{8}-\mathrm{C}_{18}\right)$ injected under the chromatography conditions described above.

\section{Cell culture}

The in vitro cytotoxicity was studied using 3T3 (normal mouse embryonic), MRC5 (normal human fibroblast), HeLa (human cervical utero carcinoma), and MCF-7 (breast can- 
cer) cells grown in liquid Dulbecco's modified Eagle's medium, and strain B16 (murine melanoma) cells were grown in HAM-F10 medium; both media were supplemented with $10 \%$ fetal bovine serum and penicillin $(100 \mathrm{U} / \mathrm{mL})$ and streptomycin $(100 \mu \mathrm{g} / \mathrm{mL})$ to prevent bacterial growth. Cells were incubated at $37^{\circ} \mathrm{C}$ in a $5 \% \mathrm{CO}_{2}$ atmosphere for 24 to $72 \mathrm{~h}$.

\section{Cytotoxicity assay}

Cell viability of was determined by the 3-(4,5-dimethylthiazol-2-yl)-2,5-diphenyltetrazolium bromide (MTT) assay, which is based on the reduction of the soluble yellow salt 3-(4,5-dimethylthiazol-2-yl)-2,5-diphenyltetrazolium bromide by mitochondrial succinate dehydrogenase, yielding the insoluble purple product formazan (Mosmann, 1983). Cells at 90\% confluence were subcultured on 96 -well plates containing $1 \times 10^{4}$ cells/well. The plates were incubated for $24 \mathrm{~h}$ to allow the cells to attach to the bottom of the wells. Subsequently, suitable culture medium for each cell type was added to plates. The culture media contained various concentrations of the essential oils from all three genotypes and thymol and carvacrol dissolved in dimethyl sulfoxide (DMSO) at $0.5 \%(\mathrm{v} / \mathrm{v})$. The plates were then incubated in an atmosphere containing $5 \% \mathrm{CO}_{2}$ for $48 \mathrm{~h}$ at $37^{\circ} \mathrm{C}$. After $48 \mathrm{~h}, 20 \mu \mathrm{L}$ MTT solution $(5 \mathrm{mg} / \mathrm{mL})$ was added, and cells were again incubated for $4 \mathrm{~h}$. At the end of this period, the cells were centrifuged at $1500 \mathrm{rpm}$ for $5 \mathrm{~min}$, and the supernatant was removed and added to $200 \mu \mathrm{L}$ DMSO. After $1 \mathrm{~h}$, the viability of the cells was determined by measuring the absorbance at $550 \mathrm{~nm}$ in an enzymelinked immunosorbent assay reader. The control (plain medium) consisted of the same number of cells cultured with medium supplemented with $0.5 \%$ DMSO. These assays were performed in triplicate with three replications. The cytotoxic activity was expressed as the $\mathrm{LC}_{50}$.

\section{Data analysis}

The cytotoxicity results were analyzed by analysis of variance, adopting a level of significance of $\mathrm{P}<0.05$.

\section{RESULTS AND DISCUSSION}

Among the three genotypes analyzed of L. gracilis, LGRA-201 had the highest essential oil content (4.65\%), followed by LGRA-106 (3.25\%) and LGRA-109 (2.70\%). Thymol (40.52\%), $\gamma$-terpinene (8.29\%), p-cymene (8.00\%), methyl thymol $(7.94 \%)$, and $\beta$-caryophyllene $(6.45 \%)$ were the predominant compounds from the LGRA-106 genotype. LGRA-109 contained carvacrol (45.84\%), p-cymene (12.47\%), $\gamma$-terpinene $(12.81 \%)$, $\beta$-caryophyllene (5.38\%), and methyl thymol (5.11\%) as the major compounds. The LGRA-201 genotype also contained carvacrol $(32.60 \%)$ as the major compound, followed by $\gamma$-terpinene (25.91\%), p-cymene (12.40\%), $\beta$-caryophyllene (5.79\%), and thymol (5.57\%) (Table 2).

The obtained results showed that the essential oils that were analyzed in this study have different chemical profiles. The LGRA-109 genotype is characterized by the most diverse constituent profile, and methyl carvacrol, acetate carvacrol, aromadendrene, $2,4-\beta$-bisabolene, and 2,4-dimethoxyacetophenone, which were present in small quantities, were only observed in this genotype. Remarkably, the observed differences in the chemical composition of the three genotypes may be attributable to genetic differences because these genotypes were grown under the same environmental conditions and collected during the same period. 


\begin{tabular}{|c|c|c|c|c|c|c|c|}
\hline \multirow[t]{3}{*}{ Compound } & \multirow[t]{3}{*}{ RRI } & \multicolumn{6}{|c|}{ GC (\%) } \\
\hline & & \multicolumn{2}{|c|}{ LGRA-106 } & \multicolumn{2}{|c|}{ LGRA-109 } & \multicolumn{2}{|c|}{ LGRA-201 } \\
\hline & & MS & FID & MS & FID & MS & FID \\
\hline$\alpha$-Thujene & 930 & 1.00 & 1.25 & 1.23 & 1.49 & 1.37 & 1.75 \\
\hline$\alpha$-Pinene & 939 & 0.44 & 0.51 & 0.30 & 0.35 & 0.36 & 0.47 \\
\hline Camphene & 954 & - & - & - & - & 0.25 & 0.23 \\
\hline Sabinene & 975 & 0.27 & 0.19 & - & - & - & - \\
\hline$\beta$-Pinene & 979 & 0.29 & 0.29 & - & - & - & - \\
\hline Myrcene & 990 & 2.45 & 3.03 & 1.84 & 2.25 & 2.45 & 3.13 \\
\hline$\alpha$-Phellandrene & 1002 & - & - & - & - & 0.35 & 0.28 \\
\hline$\alpha$-Terpinene & 1017 & 1.42 & 1.63 & 1.93 & 2.26 & 2.99 & 3.51 \\
\hline p-Cymene & 1024 & 6.40 & 8.00 & 9.25 & 12.47 & 10.14 & 12.40 \\
\hline Limonene & 1029 & 0.29 & 0.71 & 0.58 & 0.83 & 0.34 & 0.95 \\
\hline 1,8-Cineole & 1031 & 3.08 & 3.54 & - & - & 1.04 & 1.41 \\
\hline$\gamma$-Terpinene & 1059 & 6.90 & 8.29 & 10.33 & 12.81 & 21.78 & 25.91 \\
\hline Linalool & 1096 & 0.48 & 0.42 & 0.57 & 0.65 & 0.54 & 0.53 \\
\hline Borneol & 1169 & - & - & - & - & 0.54 & 0.43 \\
\hline Terpinen-4-ol & 1177 & 0.66 & 0.71 & 0.69 & 0.63 & 0.66 & 0.60 \\
\hline Methyl thymol & 1235 & 8.08 & 7.94 & 5.27 & 5.11 & - & - \\
\hline Methyl carvacrol & 1244 & - & - & 0.31 & 0.38 & - & - \\
\hline Thymol & 1290 & 43.80 & 40.52 & 3.52 & 3.07 & 6.45 & 5.57 \\
\hline Carvacrol & 1298 & 15.73 & 14.56 & 50.67 & 45.84 & 38.78 & 32.60 \\
\hline Carvacrol acetate & 1372 & - & & 0.64 & 0.47 & - & - \\
\hline$\beta$-Caryophyllene & 1419 & 6.46 & 6.45 & 6.14 & 5.38 & 6.73 & 5.79 \\
\hline$\alpha$-Trans-bergamotene & 1434 & - & - & 0.33 & 0.25 & 0.28 & 0.25 \\
\hline Aromadendrene & 1441 & - & - & 0.26 & 0.23 & - & - \\
\hline$\alpha$-Humulene & 1454 & 0.47 & 0.37 & 0.38 & 0.29 & 0.59 & 0.48 \\
\hline 2,4-Dimethoxyacetophenone & 1476 & - & - & 0.70 & 0.54 & - & - \\
\hline 2,5-Dimethoxyacetophenone & 1482 & - & - & 0.51 & 0.42 & 0.66 & 0.57 \\
\hline Bicyclogermacrene & 1500 & 0.60 & 0.57 & 1.65 & 1.41 & 2.10 & 1.80 \\
\hline$\beta$-Bisabolene & 1505 & - & - & 0.35 & 0.28 & - & - \\
\hline Spathulenol & 1578 & - & - & 0.55 & 0.42 & 0.61 & 0.40 \\
\hline Caryophyllene oxide & 1583 & 0.78 & 0.56 & 1.02 & 0.82 & 0.74 & 0.63 \\
\hline Viridiflorol & 1595 & 0.40 & 0.22 & 0.50 & 0.40 & - & - \\
\hline Essential oil content $(\%)$ & & 3.25 & & 2.70 & & 4.65 & \\
\hline
\end{tabular}

$\overline{\mathrm{GC}}=$ gas chromatograph; $\mathrm{RRI}=$ relative retention index; $\mathrm{MS}=$ mass spectrometer; FID $=$ flame ionization detector.

The cytotoxic activities of these essential oils were investigated using tumor and normal cell lines (Table 3). Among the essential oils tested, the oil from LGRA-106 exhibited the highest activity, with an $\mathrm{LC}_{50}$ of $15.62 \mu \mathrm{g} / \mathrm{mL}$ against the $\mathrm{B} 16$ murine melanoma cell line. These cells were more sensitive to thymol, which had an $\mathrm{LC}_{50}$ of $7.81 \mu \mathrm{g} / \mathrm{mL}$. The LGRA106 essential oil and its major compound thymol exhibited greater cytotoxic effects, with $\mathrm{LC}_{50}$ values of 31.25 and $15.62 \mu \mathrm{g} / \mathrm{mL}$, respectively, for the two normal cell lines, 3T3 and MRC5, demonstrating that the activity of L. gracilis essential oil is not selective for tumor cells. Among the genotypes tested, only LGRA-109 had an LC $_{50}$ value above $100 \mu \mathrm{g} / \mathrm{mL}$ for the MRC5 cell line. A striking compound was carvacrol, which had an $\mathrm{LC}_{50}$ of $31.25 \mu \mathrm{g} / \mathrm{mL}$ against MCF-7 breast cancer cells, the leading cancer affecting women in Brazil according to reports in the literature (Pacheco et al., 2011). Furthermore, the $\mathrm{LC}_{50}$ for MCF-7 cells was one-half that for the normal cell lines (3T3 and MRC5).

The monoterpenes carvacrol and thymol are isomeric. Despite having the same molecular formula, they exhibit different levels of cytotoxic activity against normal cell lines. Carvacrol was 4-fold less toxic than thymol for both normal cell lines.

The strong cytotoxic activity of the LGRA-106 essential oil can be explained by the high level of thymol in this oil. The cytotoxic activity of this substance was reported in the 
literature (Stammati et al., 1999; Chang et al., 2000; Herrmann and Wink, 2011), and its effects are already relatively well known. Thymol is believed to act through the disruption of membrane fluidity and permeability. In bacteria and fungi, this activity is nonspecific, which makes the development of resistance to this compound rare (Herrmann and Wink, 2011).

Table 3. Cytotoxic activity of the essential oils from the leaves of Lippia gracilis LGRA-106, LGRA-109, and LGRA-201 and their major components thymol and carvacrol against tumor and normal cell lines.

\begin{tabular}{|c|c|c|c|c|c|}
\hline \multirow[t]{2}{*}{ Compounds } & $\mathrm{HeLa}$ & B16 & MCF-7 & $3 \mathrm{~T} 3$ & MRC-5 \\
\hline & \multicolumn{5}{|c|}{$\mathrm{LC}_{50}(\mu \mathrm{g} / \mathrm{mL})$} \\
\hline LGRA-106 & $31.25(6.59)$ & $15.62(1.59)$ & $62.50(5.37)$ & $31.25(2.26)$ & $31.25(7.46)$ \\
\hline LGRA-109 & $125.00(4.53)$ & $62.50(3.46)$ & $62.50(1.15)$ & $62.50(2.20)$ & $125.00(3.83)$ \\
\hline LGRA-201 & $62.50(4.82)$ & $31.25(5.16)$ & $62.50(3.06)$ & $62.50(5.09)$ & $62.50(5.09)$ \\
\hline Thymol & $15.62(1.61)$ & $15.62(1.59)$ & $31.25(9.05)$ & $15.62(4.67)$ & $15.62(3.91)$ \\
\hline Carvacrol & $31.25(4.85)$ & $62.50(7.84)$ & $31.25(4.17)$ & $62.50(5.47)$ & $62.50(5.87)$ \\
\hline Doxorubicin & $2.00(7.14)$ & $1.00(3.19)$ & $4.00(3.19)$ & $8.00(4.14)$ & $8.00(7.29)$ \\
\hline
\end{tabular}

The nonspecific activity explains the overall applicability of this molecule in chemical defense in the plant kingdom. These monoterpenes are small lipophilic molecules that can easily penetrate the lipid bilayer of a biomembrane and can this way accumulate within the bilayer and increase its fluidity. Thymol is a phenol that can dissociate to form a phenolate ion under physiological conditions. After dissociation, the polar part of the molecule will accumulate at the borders of the membrane (Herrmann and Wink, 2011).

In addition to using thymol as a chemical marker of the activities of $L$. gracilis essential oils, we must also consider that these essential oils are complex substances, and their components may have synergistic effects. In these cases, there is generally more than one chemical constituent that contributes to the synergistic cytotoxic activity. For example, $\beta$-caryophyllene was observed to have a strong enhancing effect on substances with anticancer activity in the studies by Legault and Pichette (2007). When the activities of $\alpha$-humulene, isocaryophyllene, and paclitaxel were tested against MCF-7 tumor, DLD-1, and L-929 cells at $32 \mu \mathrm{g} / \mathrm{mL}, \alpha$-humulene and isocaryophyllene inhibited MCF-7 cell proliferation by 50 and $69 \%$, respectively. At $32 \mu \mathrm{g} / \mathrm{mL}$, the inhibitory activities of isocaryophyllene and $\alpha$-humulene against MCF-7 cells increased to 75 and $90 \%$ when combined with $10 \mathrm{mg} / \mathrm{mL} \beta$-caryophyllene. The activity of paclitaxel against the DLD-1 cell line increased 10-fold when combined with $\beta$-caryophyllene.

In this study, L. gracilis (LGRA-106) essential oil containing $40.52 \%$ thymol presented an $\mathrm{LC}_{50}$ value of $62.5 \mu \mathrm{g} / \mathrm{mL}$ in the MCF-7 cell line. de Medeiros et al. (2011) reported the mean $\mathrm{LC}_{50}$ value of $217.28 \mu \mathrm{g} / \mathrm{mL}$ for normal rat cells. Thymol accounted for $78.37 \%$ of this essential oil. These data suggest that the cytotoxic potential of $L$. gracilis essential oils may be associated with the presence of various chemical compounds, including thymol.

Our results are very significant because this is the first time that the cytotoxic activity of $L$. gracilis essential oil was evaluated using human cells.

\section{ACKNOWLEDGMENTS}

Research supported by CNPq (Conselho Nacional de Desenvolvimento Científico e Tecnológico), FAPITEC/SE (Fundação de Apoio à Pesquisa e à Inovação Tecnológica do Estado de Sergipe), and CAPES (Coordenação de Aperfeiçoamento de Pessoal de Nível Superior). 


\section{REFERENCES}

Adams RP (2007). Identification of Essential Oil Components by Gas Chromatography/Mass Spectrometry. 4th edn. Allured Publishing Corporation, Carol Stream.

Albuquerque CC, Camara TR, Mariano RLR, Willadino L, et al. (2006). Antimicrobial action of the essential oil of Lippia gracilis Schauer. Braz. Arch. Biol. Technol. 49: 527-535.

Chang YC, Tai KW, Huang FM and Huang MF (2000). Cytotoxic and nongenotoxic effects of phenolic compounds in human pulp cell cultures. J. Endod. 26: 440-443.

Correa-Royero J, Tangarife V, Durán C, Stashenko E, et al. (2010). In vitro antifungal activity and cytotoxic effect of essential oils and extracts of medicinal and aromatic plants against Candida krusei and Aspergillus fumigatus. Rev. Bras. Farmacogn. 20: 734-741.

de Medeiros M, da Silva AC, Citó AM, Borges AR, et al. (2011). In vitro antileishmanial activity and cytotoxicity of essential oil from Lippia sidoides Cham. Parasitol. Int. 60: 237-241.

Duarte MC, Figueira GM, Sartoratto A, Rehder VL, et al. (2005). Anti-Candida activity of Brazilian medicinal plants. $J$. Ethnopharmacol. 97: 305-311.

Ehlert PAD, Blank AF, Arrigoni-Blank MF, Paula JWA, et al. (2006). Hydrodistillation time for essential oil extraction of seven medicinal plant species. Rev. Bras. Plant Med. 8: 79-80.

Ferraz A, Faria DH, Benneti MN, da Rocha AB, et al. (2005). Screening for antiproliferative activity of six southern Brazilian species of Hypericum. Phytomedicine 12: 112-115.

Guilhon CC, Raymundo LJ, Alviano DS, Blank AF, et al. (2011). Characterisation of the anti-inflammatory and antinociceptive activities and the mechanism of the action of Lippia gracilis essential oil. J. Ethnopharmacol. 135: 406-413.

Hernández T, Canales M, Avila JG, Duran A, et al. (2003). Ethnobotany and antibacterial activity of some plants used in traditional medicine of Zapotitlán de las Salinas, Puebla (México). J. Ethnopharmacol. 88: 181-188.

Herrmann F and Wink M (2011). Synergistic interactions of saponins and monoterpenes in HeLa cells, Cos7 cells and in erythrocytes. Phytomedicine 18: 1191-1196.

Instituto Nacional do Câncer (2012). Estimativas 2012: Incidência de Câncer no Brasil. Available at [http://www1.inca. gov.br/conteudo_view.asp?id=322]. Accessed March 25, 2012.

Legault J and Pichette A (2007). Potentiating effect of beta-caryophyllene on anticancer activity of alpha-humulene, isocaryophyllene and paclitaxel. J. Pharm. Pharmacol. 59: 1643-1647.

Mesa-Arango AC, Montiel-Ramos J, Zapata B, Durán C, et al. (2009). Citral and carvone chemotypes from the essential oils of Colombian Lippia alba (Mill.) N.E. Brown: composition, cytotoxicity and antifungal activity. Mem. Inst. Oswaldo Cruz 104: 878-884.

Mosmann T (1983). Rapid colorimetric assay for cellular growth and survival: application to proliferation and cytotoxicity assays. J. Immunol. Methods 65: 55-63.

Mukherjee AK, Basu S, Sarkar N and Ghosh AC (2001). Advances in cancer therapy with plant based natural products. Curr. Med. Chem. 8: 1467-1486.

Pacheco MN, Detoni Filho A and Melo DAS (2011). Fisioterapia para o tratamento do linfedema no pós-operatório de mastectomia: revisão de literatura. Rev. Fac. Ciênc. Méd. Sorocaba 13: 4-7.

Pessoa ODL, Carvalho CBM, Silvestre JOVL, Lima MCL, et al. (2005). Antibacterial activity of the essential oil from Lippia aff. gracilis. Fitoterapia 76: 712-714.

Silva WJ, Doria GA, Maia RT, Nunes RS, et al. (2008). Effects of essential oils on Aedes aegypti larvae: alternatives to environmentally safe insecticides. Bioresour. Technol. 99: 3251-3255.

Stammati A, Bonsi P, Zucco F, Moezelaar R, et al. (1999). Toxicity of selected plant volatiles in microbial and mammalian short-term assays. Food Chem. Toxicol. 37: 813-823.

Vandendool H and Kratz PD (1963). A generalization of the retention index system including linear temperature programmed gas-liquid partition chromatography. J. Chromatogr. 11: 463-471.

Xavier AL (2011). Estudo do Potencial Antitumoral do Óleo Essencial das Folhas de Lippia microphylla cham. (Verbenaceae) e sua Toxicidade. Master's thesis, Programa de Pós-Graduação em Produtos Naturais e Sintéticos Bioativos, UFPB, João Pessoa. 